\title{
Morphometric Variability among Populations of Euglossa cordata (Hymenoptera: Apidae: Euglossini) from Different Phytophysiognomies
}

\author{
LS CARNEIRO $^{1,2}$, CML AGUIAR $^{1}$, WM AGUIAR $^{3}$, ES ANICETO ${ }^{4}$, LA NUNES ${ }^{5}$, VS FERREIRA ${ }^{6}$ \\ 1 - Departamento de Ciências Biológicas, Universidade Estadual de Feira de Santana, Feira de Santana, Brazil \\ 2 - Centro de Biociências e Biotecnologia, Universidade Estadual do Norte Fluminense, Campos dos Goytacazes, Brazil \\ 3 - Instituto do Meio Ambiente e Recursos Hídricos, Salvador, Brazil \\ 4 - Centro de Ciências e Tecnologias Agropecuárias, Universidade Estadual do Norte Fluminense, Campos dos Goytacazes, Brazil \\ 5 - Faculdade de Tecnologia e Ciências da Bahia, Jequié, Brazil \\ 6 - Universidade Federal do Vale do Rio São Francisco, Campus de Ciências Agrárias, Petrolina, Brazil
}

\section{Article History}

\section{Edited by}

Celso Martins, UFPB, Brazil

Received

Initial acceptance

Final acceptance

Publication date

\section{Keywords}

Solitary bee, orchid bee, morphological variation, wing shape, wing size.

\section{Corresponding author}

Lázaro da S. Carneiro

Laboratório de Ciências Ambientais-LCA

Universidade Estadual do Norte Fluminense

Av. Alberto Lamego, 2000, Parque Califórnia

280136002, Campos dos Goytacazes-RJ, Brasil.

E-Mail: lazarocarneiro16@gmail.com

\begin{abstract}
Geometric morphometrics is a tool capable of measuring the response of organisms to different environmental pressures. We tested the hypothesis that $E$. cordata wing morphometry, as an indicator of response to environmental pressure, it would vary depending on habitat changes, in the Atlantic Forest, Savanna and dry forest (Caatinga). For analysis of wing shape and size, 18 landmarks were digitized at the intersections of the wing veins 348 individuals. Except for the two populations sampled in Chapada Diamantina, the wing shape had significant statistical variations among the populations $(p<0.05)$. The wing size variation was also statistically significant among populations $(p<0.05)$. Although E. cordata is a species tolerant to different environments, the observed morphometric variability may be related to population adaptations to the conditions of each phytophysiognomy.
\end{abstract}

\section{Introduction}

Euglossa cordata (Linnaeus, 1758) is a primitively social bee (Garófalo, 1985; Freiria et al., 2017), which pollinates plants of several botanical families, such as Orchidaceae, Apocynaceae, Bignoniaceae and Solanaceae (Silva et al., 2007; López-Uribe et al., 2008; Coelho et al., 2017; Ferreira-Caliman et al., 2018). This species has wide distribution in the Neotropical region (Moure et al., 2012), occurring in several ecosystems in Brazil (Nemésio, 2009). Furthermore, this bee is considered as indicator for dry, open and anthropic environments (Aguiar \& Gaglianone, 2008; 2012; Ferronato et al., 2017).
Bee population responses to pressures in different environments can be observed through phenotypic variations (Nunes et al., 2007; Ribeiro et al., 2019). Although it is easy to obtain samples of Euglossini males, there is not enough knowledge about morphometric variability of these insects related to different environmental gradients (e.g. Grassi-Sella et al., 2018; Ribeiro et al., 2019). This lack of studies may be related to the idea of variation absence in males of these bees, associated to haplodiploid characteristic, genetic determination of Hymenoptera, in which most variation is conserved in females (Zayed, 2009). Furthermore, genetic studies on Euglossa Latreille, 1802 species have reported that environmental heterogeneity does not result in significant genetic variations 
among populations (Dick et al., 2004; Zimmermann et al., 2011; Soro et al., 2017). This outcome seems to be related to the high dispersal capacity of these bees (Pokorny et al., 2015), which results in gene flow between populations (Cerântola et al., 2011).

However, some studies verified the efficacy of morphological characters in males to identify morphotypes and cryptic species of the genus Euglossa (Francoy et al., 2012; Quezada-Euán et al., 2015), demonstrating the importance of using males in morphometric studies. Geometric morphometrics, the study of shape and size associated with random factors (Monteiro \& Reis, 1999; Klingenberg, 2015), has been used as a tool for studies on intra and interpopulation variation in social bees species (Mendes et al., 2007; Prado-Silva et al., 2016; Combey et al., 2018) and solitary bees (Ferreira et al., 2011; Neves et al., 2012; Dellicour et al., 2017; Grassi-Sella et al., 2018). Such studies have shown the efficacy of that technique on understanding phenotypic expression of these insect populations associated to different environmental factors, such as altitude, geographic distribution, vegetation type and habitat fragmentation.

Considering that the interaction of organisms with the environment allows morphological variations, without necessarily causing genetic changes, which is a result of phenotypic plasticity (Scheiner, 1993; Schlichting \& Wund, 2014), we tested the hypothesis that E. cordata wing morphometry, as an indicator of response to environmental pressure, it would vary depending on habitat changes, in the Atlantic Forest, Savanna and dry forest (Caatinga).

\section{Material and Methods}

Study area

The sampling was carried out in five areas of Bahia state, northeast of Brazil, representing different phytophysiognomies: Dense Ombrophilous Montane Forest (DMF) and Dense Ombrophilous Submontane Forest (DSF) in the Atlantic Forest, Semideciduous Seasonal Forest (SSF) and Savanna (SAV) on the highlands regions of Chapada Diamantina, and Arboreal Caatinga (ARC), a dry phytophysiognomy typical in the northeast of Brazil (Fig 1). The distance between sampling sites ranges from $3 \mathrm{~km}$ (DMF x DSF) to $276 \mathrm{~km}$ (DSF x SAV) (Table 1).

\section{Sampling}

The populations of the Atlantic Forest (DMF and DSF) and Chapada Diamantina (SSF and SAV) were sampled between 2014-2015, while the population of Caatinga (ARC) was sampled between 2015-2016. Three hundred and sixtytwo males of $E$. cordata were used in the analysis (Table 2).

Table 1. Distance (Km) among sampling phytophysiognomies.

\begin{tabular}{ccccc}
\hline & SAV & DMF & DSF & SSF \\
\hline ARC & 222 & 216 & 219 & 209 \\
SAV & & 273 & 276 & 17 \\
DMF & & & 03 & 258 \\
DSF & & & & 261 \\
\hline
\end{tabular}

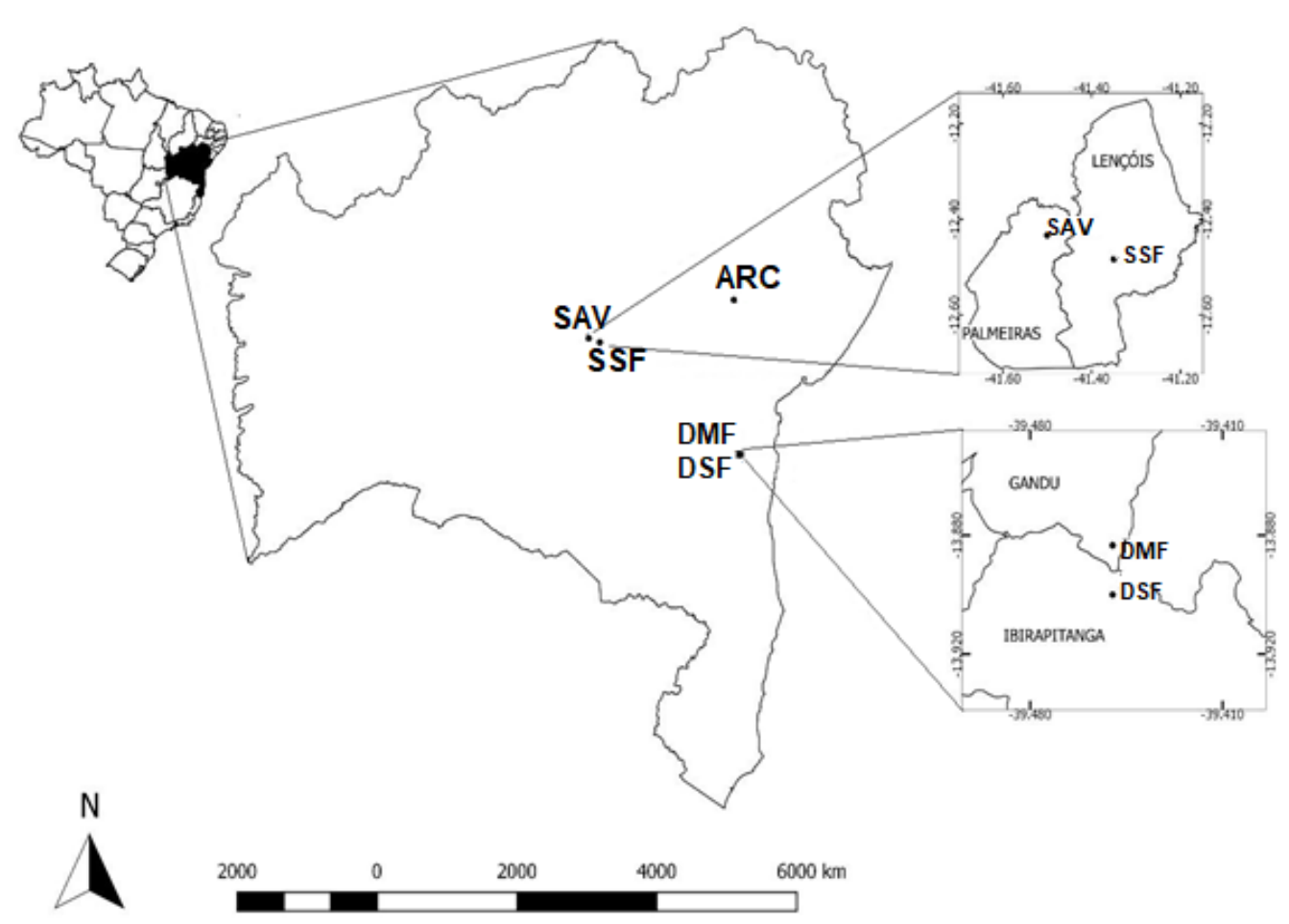

Fig 1. Phytosionomies sampled in the state of Bahia, Brazil. (DMF: Dense Ombrophilous Montane Forest; DSF: Dense Ombrophilous Submontane Forest; SSF: Semideciduous Seasonal Forest; SAV: Savanna; ARC: Arboreal Caatinga). 
Table 2. Number of individuals of Euglossa cordata (L.) analyzed in each phytophysiognomy. (ARC: Arboreal Caatinga; SAV: Savanna; SSF: Semideciduous Seasonal Forest; DMF: Dense Ombrophilous Montane Forest; DSF: Dense Ombrophilous Submontane Forest).

\begin{tabular}{cccc}
\hline Phytophysiognomy & Geographical Coordinates & Altitude (m) & Number of individuals \\
\hline ARC & $11^{\circ} 57^{\prime} \mathrm{S} 39^{\circ} 32^{\prime} \mathrm{W}$ & 235 & 46 \\
SAV & $12^{\circ} 26^{\prime} \mathrm{S} 41^{\circ} 30^{\prime} \mathrm{W}$ & 780 & 75 \\
SSF & $12^{\circ} 29^{\prime} \mathrm{S} 41^{\circ} 21^{\prime} \mathrm{W}$ & 516 & 51 \\
DMF & $13^{\circ} 53^{\prime} \mathrm{S} 39^{\circ} 27^{\prime} \mathrm{W}$ & 660 & 93 \\
DSF & $13^{\circ} 54^{\prime} \mathrm{S} 39^{\circ} 27^{\prime} \mathrm{W}$ & 500 & 97 \\
\hline Total & & & 362 \\
\hline
\end{tabular}

The bees were collected using bait traps (benzyl acetate, $\beta$-ionone, methyl cinnamate, eucalyptol, eugenol, methyl salicate and vanillin), based on the traps described by Aguiar and Gaglianone (2008).

\section{Methods}

The left forewing of each individual was removed, fixed between two slides of microscopy, and photographed in Leica stereoscopic microscope (96 dpi resolution). An image bank was created using the tpsUtil 1.6 software (Rolhf, 2013), that was opened in tpsDig 2.18 (Rolhf, 2015), in which 18 landmarks were digitized at the intersections of the wing veins (Fig 2).

\section{$2 \mathrm{~mm}$}

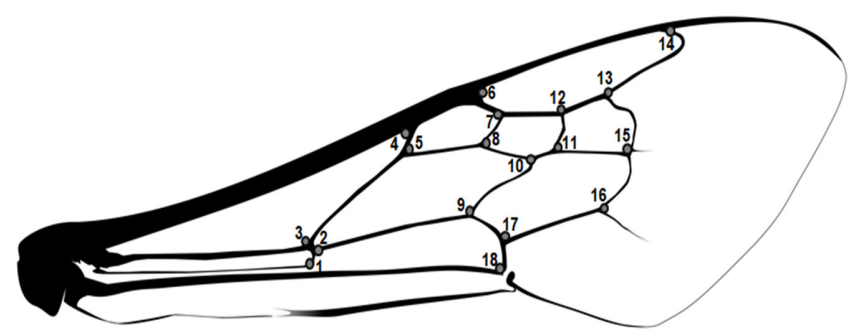

Fig 2. Landmarks plotted at the intersections of the wing veins of Euglossa cordata (L.).

\section{Data analysis}

A Procrustes superimposition was performed, eliminating any differences in size, position and orientation between configurations (Klingenberg, 2015). The Principal Component Analysis (PCA), an exploratory analysis of data, was used to observe the variation level of the sample. In order to evaluate if there were morphometric differences in the wing shape between populations, it was used Canonical Variate Analysis (CVA) and a multivariate statistical analysis (MANOVA). We have used the Procrustes distance, i.e. values generated from the minimum sum of squares of the distances between landmarks after the Procrustes superimposition (Monteiro \& Reis, 1999), were used to evaluate the similarity of the wing shape between populations. These analyzes were made in MorphoJ 1.06d software (Klingenberg, 2011).
The wing size was estimated from the centroid size, which is the square root of the sum of of the landmarks distances relative to the center of gravity (Klingenberg, 2015). Subsequently, a variance analysis (ANOVA one-away) and Tukey comparison test were carried out. Pearson's test was used to verify if there was correlation between morphometric variables (wing shape and size) and environmental and geographic variables of each area (phytophysiognomy type, altitude, longitude and latitude). These tests were performed in the PAST 2.17c program (Hammer et al., 2001).

\section{Results}

In the Principal Components Analysis (PCA), 32 components were generated, of which the first nine components explained $72.4 \%$ of variation. In the Canonical Variable Analysis (CVA), the first two variables explained more than $80 \%$ of the data variation of wing shape. The first variable explained $48.5 \%$ and separated on the positive axis DMF and SMF, and on the negative axis SSF and SAV. The second variable explained $31.6 \%$ and separated on the positive axis SAV and SMF, and on the negative axis ARC and SFF (Fig 3). The MANOVA indicated low variation in wing shape between SFF and SAV ( $p=0.05)$, and the difference in wing shape was statistically significant between the other $E$. cordata populations (Wilk's $\lambda=0.000 ; \mathrm{p}<0.05$ ).

The Procrustes distance indicated higher wing shape similarity between ARC and DMF populations, and higher dissimilarity between ARC and SAV (Table 3). Furthermore, from the test of permutation with 10.000 replicates associated to the Procrustes distance, wing shape presented significant differences between populations $(\mathrm{p}<0.05)$.

Table 3. Procrustes distance generated from the Canonical Variate Analysis (CVA) between each phytophysiognomy (lower) and $p$ value of the permutation test (10.000 permutations) (upper).

\begin{tabular}{cccccc}
\hline & ARC & SAV & DMF & DSF & SSF \\
\hline ARC & & 0.0001 & 0.0167 & 0.0001 & 0.0007 \\
SAV & 0.0104 & & 0.0001 & 0.0001 & 0.0006 \\
DMF & 0.0057 & 0.0092 & & 0.0001 & 0.0001 \\
DSF & 0.0069 & 0.0077 & 0.0064 & & 0.0001 \\
SSF & 0.0083 & 0.0074 & 0.0093 & 0.0083 & \\
\hline
\end{tabular}




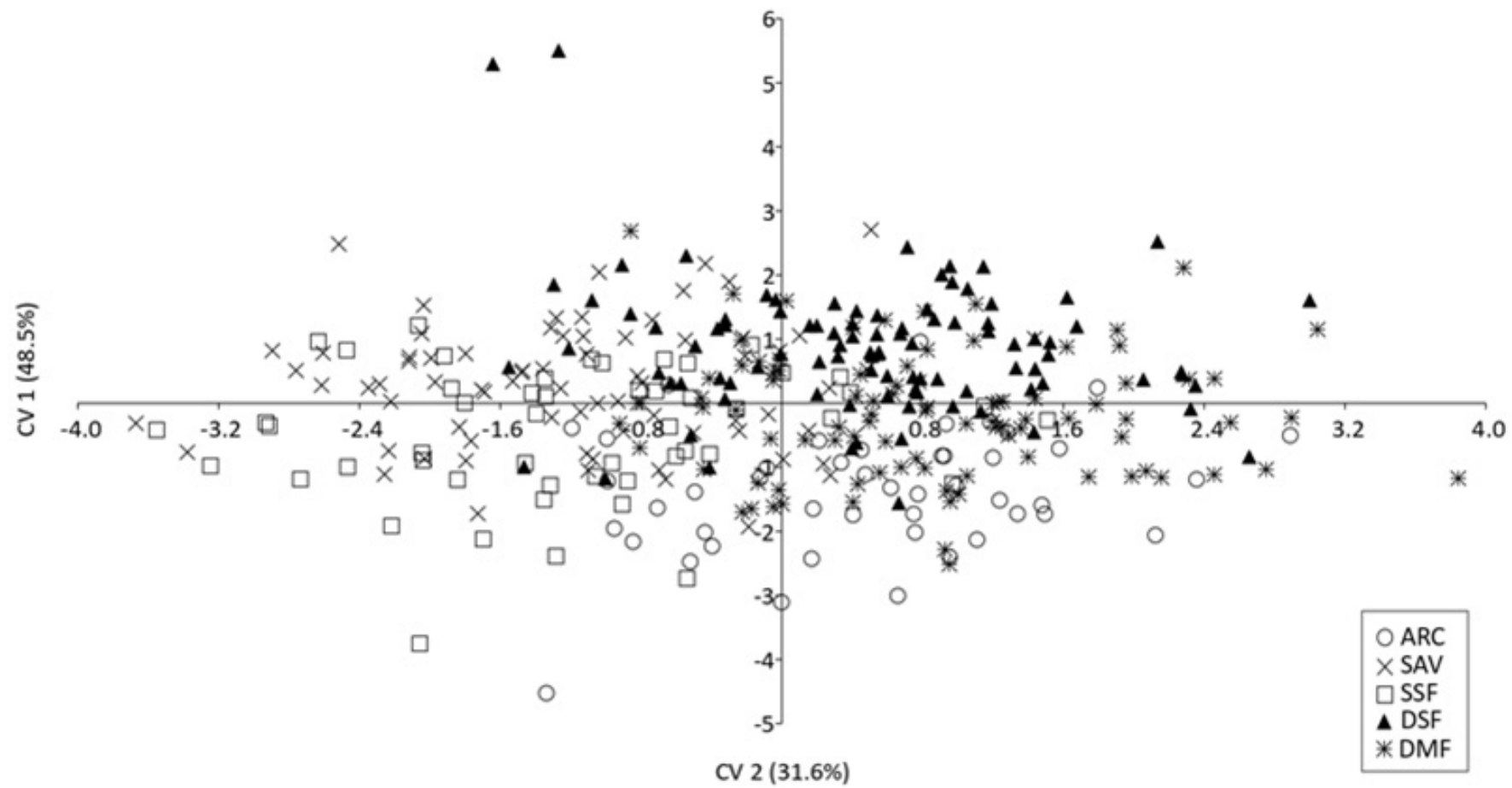

Fig 3. Scatter plot of the five populations of Euglossa cordata (L.) analyzed, generated from the two canonical variables with higher variation of the Canonical Variate Analysis (CVA).

The difference between means for wing size was statistically significant (ANOVA one way, $\mathrm{f}=10.58 ; \mathrm{p}<0.05$ ). Tukey's multiple comparison test indicated that the wings of Atlantic Forest populations differed from the others (DSF $x$ SSF, DMF x ARC, DMF x SAV, DMF x SSF).

Pearson's test indicated positive correlation between wing shape and size with altitude and latitude, and negative correlation between wing shape and size with longitude and phytophysiognomy type, with high significance $(\mathrm{p}<0.05)$ (Table 4).

Table 4. Result of Pearson linear correlation (r) between the morphometrics variables (wing shape and size), with the geographic and environmental variables.

\begin{tabular}{cccc}
\hline $\begin{array}{c}\text { Morphometric } \\
\text { Variables }\end{array}$ & Geographic Variables & $\boldsymbol{r}$ & $\mathbf{P}$ \\
\hline \multirow{3}{*}{ Wing Shape } & Altitude & 0.06 & $<0.05$ \\
& Latitude & 0.24 & $<0.05$ \\
& Longitude & -0.28 & $<0.05$ \\
& Phytophysiognomy & -0.18 & $<0.05$ \\
\hline \multirow{3}{*}{ Wing Size } & Altitude & 0.23 & 0.21 \\
& Latitude & 0.58 & $<0.05$ \\
& Longitude & -0.46 & $<0.05$ \\
& Phytophysiognomy & -0.31 & $<0.05$ \\
\hline
\end{tabular}

\section{Discussion}

Based on wing shape and size analysis, populations of E. cordata showed morphometric variability. Although this species has been indicated as tolerant to different environmental conditions (Aguiar \& Gaglianone, 2008; 2012), the occurrence of interpopulation morphometric variations may reflect different environmental pressures in each phytophysiognomy, similar to what has been observed in social bees (Nunes et al., 2007; Combey et al., 2018). On the other hand, these variations observed in wing shape of $E$. cordata between the phytophysiognomies differed from those reported for populations of Euglossa annectans Dressler, 1982 and Euglossa truncata Rebêlo and Moure, 1995 sampled in Atlantic Forest and Savanna in Brazil (Grassi-Sella et al., 2018). These authors reported the high morphological similarity between populations with the high dispersal potential of these bees. The wing shape variability may be related to factors such as genetic control, sexual selection and environmental heterogeneity (Dellicour et al., 2017). Euglossini bees present some ecological requirements that are scattered in the landscape (Roubik \& Hanson, 2004). Thus, it is possible that interpopulation wing shape variability in $E$. cordata reflects the adjustment of populations to fulfill their ecological requirements on different environments, since life history traits, such as foraging behavior, influence phenotypic adjustment (Mendoza-Cuenca \& Macías-Ordóñez, 2005).

The higher dissimilarity of $E$. cordata wing shape was observed between the populations sampled in caatinga (ARC) and savanna (SAV), although both are phytophysiognomies with open and shrub vegetation. The SAV population comes from an area of $780 \mathrm{~m}$ of altitude in the Chapada Diamantina, north region of Espinhaço moutain chain, and is separated by $222 \mathrm{~km}$ from the ARC population, which is situated at lower altitude $(235 \mathrm{~m})$. Furthermore, the geographic 
proximity between SSF (Semideciduous Seasonal Forest) and SAV areas could explain the low variation in wing shape between populations from these environments, as indicated in the MANOVA test, because although they are distinct phytophysiognomies (forest and savanna), they are close to each other $(\sim 17 \mathrm{~km})$, in the central region of the Chapada Diamantina. Nunes et al. (2007) pointed out that the Chapada Diamantina mountains are an important barrier for other bees as Melipona scutellaris Latreille, 1811, precluding gene flow.

The Procrustes distance indicated that wing shape in the Caatinga (ARC) and Atlantic Forest (DMF and DSF) populations had higher similarity. It is possible that populations from Caatinga still has some connectivity with populations in the Atlantic Forest, since these two biomes are neighbors and do not have geographic barriers separating them, which would facilitate gene flow, similar to what has been observed in other Euglossa species (Dick et al., 2004; Zimmermann et al., 2011; Soro et al., 2017).

Wing size showed significant variations between populations from the Atlantic Forest (DMF and DSF), with Caatinga (ARC), Semideciduos Seasonal Forest (SSF) and Savanna (SAV) populations. In insects, size variations are related to quality and quantity of resources provided in larval stage (Peruquetti, 2003; Campos et al., 2018). The variations found in wing size may reflect the different ways in which floral resources are offered in each environment, since the dynamics of this supply may vary temporally in each phytophysiognomy, associated with variables such as pluviosity and temperature (Morellato et al., 2000; Conceição et al., 2007). Campos et al. (2018) observed seasonal variation in the size of males and females of Tetrapedia curvitarsis Friese, 1899, which would be related to the amount of resources stored in brood cells in different seasons.

The wing shape and size of E. cordata seems to be traits that vary between habitats, which may explain the presence of correlation found among these variables with phytophysiognomy type, latitude, longitude and altitude. These morphometric variations observed may be related to different populations responses to the local environmental characteristics of each phytophysiognomy, because insects may have plastic morphological adaptations in response to altitudinal and latitudinal geographical gradients (Baranovská \& Knapp, 2018), or to local variations in landscape elements (Ribeiro et al., 2019). Grassi-Sella et al. (2018) found a pattern of morphometric clustering in E. annectans and E. truncata related to the phytophysiognomy from which the populations were sampled, being such pattern attributed to phenotypic plasticity.

Thus, environmental variations resulted in morphological variability in E. cordata, despite its wide occurrence in different environments. Genetic studies with these populations can indicate if the species presents a high interpopulation variability, which can subsidize conservation actions for these important pollinators.

\section{Acknowledgements}

We are grateful to Conselho Nacional de Desenvolvimento Científico e Tecnológico-CNPq (PELD: 474065/2013-8) and Organização de Conservação da Terra-OCT for financial support. LS Carneiro received scientific initiation fellowship from CNPq (Process 114696/2016-0). LS Carneiro and ES Aniceto receive Master fellowship from Coordenação de Aperfeiçoamento de Pessoal de Nível Superior - CAPES.

\section{References}

Aguiar, W.M. \& Gaglianone, M.C. (2008). Comunidade de abelhas Euglossina (Hymenoptera: Apidae) em remanescentes de mata Estacional Semidecidual sobre Tabuleiro no estado do Rio de Janeiro. Neotropical Entomology, 37: 118-125. doi: 10.1590/S1519-566X2008000200002

Aguiar, W.M. \& Gaglianone, M.C. (2012). Euglossine bee communities in small forest fragments of the Atlantic Forest, Rio de Janeiro state, southeastern Brazil (Hymenoptera, Apidae). Revista Brasileira de Entomologia, 56: 210-219. doi: $10.1590 / \mathrm{s} 0085-56262012005000018$

Baranovská, E., \& Knapp, M. (2018). Steep converse Bergmann's cline in a carrion beetle: Between-and withinpopulation variation in body size along an elevational gradient. Journal of Zoology, 304: 243-251. doi: 10.1111/jzo.12527

Campos, E.S., Araujo, T.N., Rabelo, L.S., Bastos, E.M.A. \& Augusto, S.C. (2018). Does Seasonality Affect the Nest Productivity, Body Size, and Food Niche of Tetrapedia curvitarsis Friese (Apidae, Tetrapediini)? Sociobiology, 65: 576-582. doi: 10.13102/sociobiology.v65i4.3395

Cerântola, N.D.C.M., Oi, C.A., Cervini, M. \& Del Lama, M.A. (2010). Genetic differentiation of urban populations of Euglossa cordata from the state of São Paulo, Brazil. Apidologie, 42: 214-222. doi: 10.1051/apido/2010055

Coelho, C.P., Gomes, D.C., Guilherme, F.A.G. \& Souza, L.F. (2017). Reproductive biology of endemic Solanum melissarum Bohs (Solanaceae) and updating of its current geographic distribution as the basis for its conservation in the Brazilian Cerrado. Brazilian Journal of Biology, 77: 809-819. doi: 10.1590/1519-6984.01516

Combey, R., Quandahor, P. \& Mensah, B.A. (2018). Geometric Morphometrics Captures Possible Segregation Occurring within Subspecies Apis Mellifera Adansonii in Three Agro Ecological Zones. Annals of Biological Research, 9: 31-43

Conceição, A.A., Funch, L.S. \& Pirani, J.R. (2007). Reproductive phenology, pollination and seed dispersal syndromes on sandstone outcrop vegetation in the Chapada Diamantina, northeastern Brazil: population and community analyses. Revista Brasileira de Botânica, 30: 475-485. doi: 10.1590/s0100-84042007000300012 
Dellicour, S., Gerard, M., Prunier, J.G., Dewulf, A., Kuhlmann, M. \& Michez, D. (2017). Distribution and predictors of wing shape and size variability in three sister species of solitary bees. PloS One, 12: e0173109. doi: 10.1371/journal. pone.0173109

Dick, C.W., Roubik, D.W., Gruber, K.F. \& Bermingham, E. (2004). Long-distance gene flow and cross Andean dispersal of lowland rainforest bees (Apidae: Euglossini) revealed by comparative mitochondrial DNA phylogeography. Molecular Ecology, 13: 3775-3785. doi: 10.1111/j.1365-294x.2004.02374.x

Ferreira, V.S., Aguiar, C.M.L., Costa, M.A. \& Silva, J.G. (2011). Morphometric analysis of populations of Centris aenea Lepeletier (Hymenoptera: Apidae) from Northeastern Brazil. Neotropical Entomology, 40: 97-102. doi: 10.1590/ s1519-566x2011000100014

Ferreira-Caliman, M.J., Rocha-Filho, L.C.D., Freiria, G.A. \& Garófalo, C.A. (2018). Floral sources used by the orchid bee Euglossa cordata (Linnaeus, 1758) (Apidae: Euglossini) in an urban area of south-eastern Brazil. Grana, 57: 471-480. doi: 10.1080/00173134.2018.1479445

Ferronato, M.C.F., Giangarelli, D.C., Mazzaro, D., Uemura, N. \& Sofia, S.H. (2017). Orchid Bee (Apidae: Euglossini) Communities in Atlantic Forest Remnants and Restored Areas in Paraná State, Brazil. Neotropical Entomology, 47: 352361. doi: 10.1007/s13744-017-0530-2

Francoy, T.M., Franco, F.F. \& Roubik, D.W. (2012). Integrated landmark and outline-based morphometric methods efficiently distinguish species of Euglossa (Hymenoptera, Apidae, Euglossini). Apidologie, 43: 609-617. doi: 10.1007/ s13592-012-0132-2

Freiria, G.A., Garófalo, C.A. \& Del Lama, M.A. (2017). The primitively social behavior of Euglossa cordata (Hymenoptera, Apidae, Euglossini): a view from the perspective of kin selection theory and models of reproductive skew. Apidologie, 48: 523-532. doi: 10.1007/s13592-017-0496-4

Garófalo, C.A. (1985). Social structure of Euglossa cordata nests (Hymenoptera: Apidae: Euglossini). Entomologia Generalis, 11: 77-83. doi: 10.1007/s13592-017-0496-4

Grassi-Sella, M.L., Garófalo, C.A. \& Francoy, T.M. (2018). Morphological similarity of widely separated populations of two Euglossini (Hymenoptera; Apidae) species based on geometric morphometrics of wings. Apidologie, 49: 151-161. doi: $10.1007 / \mathrm{s} 13592-017-0536-0$

Hammer, O., Harper, D.A.T. \& Ryan, P.D. (2001). PASTPalaeontological Statistics, ver. 1.89. Palaeontologia electronica 4(9). Retrived from: http://palaeo electronica. org/2001_1/past/past.pdf/

Klingenberg, C.P. (2011). MorphoJ: an integrated software package for geometric morphometrics. Molecular Ecology Resources, 11: 353-357. doi: 10.1111/j.1755-0998.2010.02924.x
Klingenberg, C.P. (2015). Analyzing fluctuating asymmetry with geometric morphometrics: concepts, methods, and applications. Symmetry, 7: 843-934. doi: 10.3390/sym7020843

López-Uribe, M.M., Oi, C.A. \& Del Lama, M.A. (2008). Nectar-foraging behavior of Euglossine bees (Hymenoptera: Apidae) in urban areas. Apidologie, 39: 410-418. doi: 10.10 51/apido:2008023

Mendoza-Cuenca, L. \& Macías-Ordóñez, R. (2005). Foraging polymorphism in Heliconius charitonia (Lepidoptera: Nymphalidae): morphological constraints and behavioural compensation. Journal of Tropical Ecology, 21: 407-415. doi: $10.1017 / \mathrm{s} 0266467405002385$

Mendes, M.F.M., Francoy, T.M., Nunes-Silva, P., Menezes, C. \& Imperatriz-Fonseca, V.L. (2007). Intra-populational variability of Nannotrigona testaceicornis Lepeletier, 1836 (Hymenoptera, Meliponini) using relative warps analysis. Bioscience journal, 23: 147-152

Monteiro, L.R. \& Reis, S. (1999). Princípios de morfometria geométrica. Ribeirão Preto: Holos Editora, 188 p

Morellato, L.P.C., Talora, D.C., Takahasi, A., Bencke, C.C., Romera, E.C. \& Zipparro, V.B. (2000). Phenology of Atlantic Rain Forest Trees: A Comparative Study. Biotropica, 32: 811823. doi: 10.1111/j.1744-7429.2000.tb00620.x

Moure, J.S., Melo, G.A.R. \& Faria Jr, L.R.R. (2012). Euglossini Latreille, 1802. In Moure J.S., Urban D. \& Melo G.A.R (Eds.), Catalogue of bees (Hymenoptera, Apoidea) in the Neotropical region - online version. http://www.moure. cria.org.br/catalogue/. (acessed date: 18 April, 2019)

Nemésio, A. (2009). Orchid bees (Hymenoptera: Apidae) of the Brazilian Atlantic Forest. Zootaxa, 2041: 1-242. doi: 10.11646/zootaxa.2041.1.1

Neves, C.M.L., Carvalho, C.A.L., Souza, A.V. \& Junior, C.A.L. (2012). Morphometric Characterization of a Population of Tetrapedia diversipes in Restricted Areas in Bahia, Brazil (Hymenoptera: Apidae). Sociobiology, 59: 767-782.

Nunes, L.A., Da Costa, M.D.F.F., Carneiro, P.L.S., Pereira, D.G. \& Waldschmidt, A.M. (2007). Divergência genética em Melipona scutellaris Latreille (Hymenoptera: Apidae) com base em caracteres morfológicos. Bioscience Journal, 23: 1-9.

Peruquetti, R.C. (2003). Variação do tamanho corporal de machos de Eulaema nigrita Lepeletier (Hymenoptera, Apidae, Euglossini). Resposta materna à flutuação de recursos? Revista Brasileira de Zoologia, 20: 207-212. doi: 10.1590/ s0101-81752003000200006

Pokorny, T., Loose, D., Dyker, G., Quezada-Euán, J.J.G. \& Eltz, T. (2015). Dispersal ability of male orchid bees and direct evidence for long-range flights. Apidologie, 46: 224237. doi: 10.1007/s13592-014-0317-y

Prado-Silva, A., Nunes, L.A., Oliveira Alves, R.M., Carneiro, 
P.L.S. \& Waldschmidt, A.M. (2016). Variation of fore wing shape in Melipona mandacaia Smith, 1863 (Hymenoptera, Meliponini) along its geographic range. Journal of Hymenoptera Research, 48: 85-94. doi: 10.3897/jhr.48.6619

Quezada-Euán, J.J.G., Sheets, H.D., De Luna, E. \& Eltz, T. (2015). Identification of cryptic species and morphotypes in male Euglossa: morphometric analysis of forewings (Hymenoptera: Euglossini). Apidologie, 46: 787-795. doi: 10.1007/s13592-015-0369-7

Ribeiro, M., Aguiar, W.M., Nunes, L.A. \& Carneiro, L.S. (2019). Morphometric Changes in Three Species of Euglossini (Hym.: Apidae) in Response to Landscape Structure. Sociobiology, 66: 339-347. doi: 10.13102/sociobiology.v66i2.3779

Rohlf, F.J. (2015). tpsDig v2.18. Department of Ecology and Evolution: State University of New York, Stony Brook, New York

Rohlf, F.J. (2013). tpsUtil version 1.6. Department of Ecology and Evolution: State University of New York at Stony Brook

Roubik, D.W. \& Hanson, P.E. (2004). Orchids bees of tropical America: biology and field guide. INBio Press: Heredia, Costa Rica

Scheiner, S.M. (1993). Genetics and Evolution of Phenotypic Plasticity. Annual Review of Ecology and Systematics, 24: 35-68. doi: 10.1146/annurev.ecolsys.24.1.35
Schlichting, C.D. \& Wund, M.A. (2014). Phenotypic plasticity and epigenetic marking: an assessment of evidence for genetic accommodation. Evolution, 68: 656-672. doi: 10.1111/evo.12348

Silva, C.I., Augusto, S.C., Sofia, S.H. \& Moscheta, I.S. (2007). Diversidade de abelhas em Tecomastans (L.) Kunth (Bignoniaceae): Importância na polinização e produção de frutos. Neotropical Entomology, 36: 331-341. doi: 10.1590/ s1519-566x2007000300002

Soro, A., Quezada-Euán, J.J.G., Theodorou, P., Moritz, R.F. \& Paxton, R.J. (2017). The population genetics of two orchid bees suggests high dispersal, low diploid male production and only an effect of island isolation in lowering genetic diversity. Conservation Genetics, 18: 607-619. doi: 10.1007/s10592016-0912-8

Zayed, A. (2009). Bee genetics and conservation. Apidologie, 40: 237-262. doi: 10.1051/apido/2009026. doi: 10.1007/s10 592-011-0221-1

Zimmermann, Y., Schorkopf, D.L.P., Moritz, R.F.A., Pemberton, R.W., Quezada-Euán, J.J.G. \& Eltz, T. (2011). Population genetic structure of orchid bees (Euglossini) in anthropogenically altered landscapes. Conservation Genetics, 12: 1183-1194. doi: 10.1007/s10592-011-0221-1

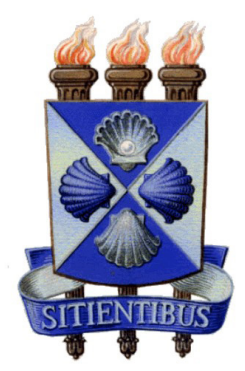

